\title{
The role of agriculture finance in modern technologies adoption for enhanced productivity and rural household economic wellbeing in Ghana: A case study of rice farmers in Shai-Osudoku District.
}

\author{
Evans Sackey Teye ${ }^{1 *}(\dagger) \&$ Philip Tetteh Quarshie ${ }^{23}(\dagger)$ \\ ${ }^{1}$ School of Public Services and Governance, Ghana Institute of Management and Public \\ Administration, Accra, Ghana \\ ${ }^{2}$ Department of Geography Environment and Geomatics, University of Guelph, Ontario, Canada \\ ${ }^{3}$ Guelph Institute of Development Studies, University of Guelph, Ontario, Canada \\ *Corresponding author \\ P.O. Box CE 12116, Tema, Ghana \\ Email: teyeevans@yahoo.com
}

\begin{abstract}
Rural and agricultural finance innovations have significant potential to improve the livelihoods and food security of the poor. Although microfinance has been widely studied, an extensive knowledge gap still exists on the nuts and bolts of expanding access to rural and agricultural finance. This study uses focus group discussion, key informant interview, and quantitative household survey to explore how smallholders access credits and loans influence adoption of modern production technologies and what are perceived limitations to access these financial instruments in the Shia-Osuduku District in the Greater Accra Region of Ghana. The specific objectives of the study are; (1) to assess the challenges rice farmers face in accessing finance, (2) to determine if access to finance impacts the adoption of modern rice production technologies and (3) to determine whether loan investments in improved technologies increase productivity and income levels of farmers. The study noted that issues of mistrust for smallholder farmers by financial institutions act as barriers to facilitating their access to loans and credits. Banks and financial institutions relay their mistrust through actions such as requesting outrageous collateral, guarantors, a high sum of savings capital, and a high-interest rate for agriculture loans, delays, and bureaucratic processes in accessing loans. The study suggested that enabling policy environment and frameworks with a supportive rural infrastructure such as warehouse receipt systems can significantly increase farmers' access to credit instruments for investment in modern technologies to increase agricultural productivity, which is essential to address issues of food insecurities and rural poverty in Ghana.
\end{abstract}

Keywords: Credits instrument, agricultural finance, loans, improved technologies, smallholder farmers, Ghana 


\section{Introduction}

There is optimism that agriculture and agribusiness, which remain the mainstay of economies of nations, particularly in Sub-Saharan Africa (SSA), can achieve food security and rural development (Lin et al., 2001; Holt Giménez \& Shattuck, 2011). According to the United Nations Development Programme (UNDP), growth in Sub-Saharan Agriculture is twice as effective as ending hunger and reducing poverty compared to growth in other sectors of the economies (UNDP, 2017). However, many argue much investment in the area of agricultural financing are needed to upscale improved planting technologies such as high-yielding seeds varieties, farm management practices, integrated soil fertility management and integrated pest management by smallholder farmers to realize the full potential of smallholding agriculture in SSA (Evans, 2009; Poultron et al., 2010). Unfortunately, the high levels of poverty and the lack of access to sustainable financial services among rural farmers make it virtually impossible for smallholders to access financial instruments to adopt these technologies, which are essential to improve agricultural productivity and rural development (Ayanlade \& Radeny, 2020; Gassner et al., 2019; Mausch et al., 2018). Collectively, these constraints undermine agricultural sustainability by exacerbating rural poverty levels and food insecurities in the region (Godfray \& Garnett, 2014; Kc et al., 2016).

Whiles the impact of financial access in a rural agricultural area may differ from its impact in an urban context where there is industrialization (Keyoung, 2011). The need to design innovative financial products for smallholder farmers by credits and financial institutions to promote widespread adoption of improved technologies is one echoed by governments, academicians, and development partners (AGRA, 2020; Ali et al., 2020; Ayanlade \& Radeny, 2020; Banerjee \& Duflo, 2011). This paper explores how smallholders' access to credits and loans influence the adoption of modern production technologies and the perceived limitations of accessing these financial instruments in the Shia-Osuduku District in the Greater Accra Region of Ghana. Specifically, the study draws insight from the induced innovation theory and theory of failed-market induced behaviour to explore and understand the following specific objectives; (1) to assess the challenges rice farmers face in accessing finance in the Shai-Osudoku district; (2) determine if access to finance impacts on the adoption of modern rice production technologies; and (3) determine whether access to loans and credits improves productivity and income levels of farmers in the Shai-Osudoku District. The paper is divided into five sections; (1) background context and literature review, (2) research design and settings, (3) study result and findings,

(4) Discussion, (5) recommendations, which explores policies required to improved farmers access to financial products for widespread technology adoption. The conclusion reiterates the research findings 
and the need to invest in mechanisms that enhance smallholders' access to agricultural loans and credits for widespread adoption of modern technologies to achieve food security and rural household economic wellbeing.

The decision to focus research on rice is because rice follows maize as the second most important food security crop in Africa and a major source of income for rural farmers (Ayanlade \& Radeny, 2020). In Ghana, rice is the second most important cereal after maize and is fast becoming a cash crop for many farmers (MoFA 2016; Osei-Asare, 2010). National and agricultural development plans and strategies, such as the Ghana Poverty Reduction Strategy (GPRS I), Growth and Poverty Reduction Strategy (GPRS II), Food and Agricultural Sector Development Policy (FASDEP) I and II, Medium Term Agriculture Sector Investment Plan (METASIP), and Accelerated Agricultural Growth and Development Strategy (AAGDS), have featured rice as one of the targeted food security crops (Boansi \& Favour, 2015). Annual per capita consumption of rice is growing rapidly, from 17.5 kilograms in 1999-2001 to 22.4 kilograms in 2002-2004 and 24 kilograms in 2010-2011 (MOFA, 2016), and rice demand is projected to grow at a compound annual growth rate of 11.8 percent and maize at 2.6 percent in the medium term (MoFA, 2016; 2017).

This research draws insight from induced innovation theory (Ruttan \& Hayami, 1984; Rogers, 2003) and failed-market induced behaviour (de Janvry \& Sadoulet, 2006; Amadu et al., 2020) to understand the impact of financial services provisioning in influencing farmers' decision to adopt improved planting technologies. These theories have been used extensively to understand the determinant of technology adoption in SSA (e.g. Atilaw et al., 2017; Adeogun et al. 2010; Adesina \& Baidu-Forson, 1995; Caswell et al., 2001; Ainissyifa et al., 2018; Buah et al., 2011; Doss \& Morris, 2001). However, there is limited literature on how these theories are used to show how access to financial credit influences farmers' decision to adopt modern technologies and how adopting these technologies leads to agricultural productivity and improved wellbeing of rural households in SSA. Furthermore, while efforts have been made across scales to influence the adoption of improved planting technologies among Africa's rural farmers to transform smallholding agriculture in the region (AGRA, 2020; Kansanga et al., 2018; Nyantakyi-Frimpong et al., 2015; Vercillo \& Hird-Younger, 2019), studies continue to show that adoption rate of modern technologies is low among Africa's rural farmers (Amadu et al., 2020; Quarshie et al., 2021). The low adoption rate of improved technologies to increase agricultural productivity has exacerbated the region's high level of rural poverty and food insecurities (Foley et al., 2011; Tilman et al., 2011). A situation that undermines global effort to achieve food 
security (KC et al., 2016). Therefore this study explores how access to financial credits by smallholders is critical to influencing farmers' decision to adopt improved technologies for agricultural productivity and rural household economic wellbeing.

\section{Background Context}

\subsection{Smallholding Agriculture in Sub-Saharan Africa}

Agriculture is the primary business source of livelihood and major economic sector for nations in SSA. The sector is dominated by smallholder farmers who constitute about $65 \%$ of the total population in the region and contribute about 25\% to the GDPs of nations in the region (AGRA, 2020; World Bank Group, 2019). Agriculture and agribusiness employ almost 70\% of the region's poor households who produce about $85 \%$ of the continent's food from an average of less than 2 ha farmlands (Lowder et al., 2016). The sector is plagued with mirades of challenges ranging from poor access to input, lack of adequate extension services delivery, poor institutional and market access and farmers' inability to access finance to adopt improved planting technologies (Banerjee \& Duflo, 2011; Gassner et al., 2019).

The contribution of the sector to the economies of nations in SSA has witnessed a decline by $6 \%$ from $2000-2013$ as a result of challenges such as high incidence of poverty among rural farmers, land degradation, climate change and more recently, the impact of the covid-19 pandemic and its concomitant measures put in place to curb the spread of the virus (Ali et al., 2020; Ayanlade \& Radeny, 2020). The situation has prompted some researchers to conclude that the prospect of Africa's agriculture as a tool for food security and rural poverty reduction within a rapidly changing climatic condition is bleak (Thornton et al., 2011).

To address the challenge of low agriculture productivity and high levels of poverty and malnutrition among rural populations in Africa was the African green revolution agenda that promoted the development of smallholder and modernized agriculture. Promoted by international agencies including the Rockefeller Foundation and the Bill and Melinda Gates Foundation (BMGF), the G7s New Alliance for Food Security and Nutrition in Africa (NAFSNA), the United States Agency for International Development (USAID) and the African Union's Comprehensive African Agricultural Development Program (CAADP) under the umbrella of the Alliance for a Green Revolution in Africa (AGRA), the agenda have driven policies that seek to alter the conditions of farming, particularly for Africa's smallholders (Dawson et al., 2016; Nin-Pratt \& McBride, 2014; Vercillo et al., 2015). Central within a suite of policy directions promoted by this vision is the modernization of farming through high-input 
agricultural systems integrated into markets, with the effective participation of the private sector and non-governmental actors. Hence, mechanization, irrigation, commercialization (of input and output markets), application of soil enhancements (fertilizers) and crop protection chemicals (or sometimes pesticides), and more importantly, the embracement of High-Yielding Varieties (HYV) configured to increase outputs and close yield gaps in the region are at the core of the revolution (see Howard et al., 2003; Juma, 2015; Nin-Pratt \& McBride, 2014). Yet, again older models of Green revolution in Asia or Africa earlier were state and government anchored the directions and implementation of the suit of strategies, the new green revolution fetishes an ideology of market integration for smallholders and private sector-led growth (Amanor, 2011) through a partnership that seeks to enhance farmers access to finance and credits to enable them to adopt these improved planting technologies (Poulton et al., 2010). According to Evans (2009), an excellent enabling environment that gives smallholders access to credits for widespread adoption of green revolution technologies is a viable tool for agricultural productivity and rural poverty reduction in developing nations.

\subsection{Theoretical Concept}

This research draws insight from induced innovation theory (Ruttan \& Hayami, 1984; Rogers, 2003) and failed-market induced behaviour (de Janvry \& Sadoulet, 2006; Amadu et al., 2020) to understand the impact of financial services provisioning in influencing farmers' decision to adopt improved planting technologies. The induced innovation theory posits that the comparative advantage of improved technologies which is a function of the cost involved to access and utilize a particular technology, influences farmers decision to adopt or not to adopt any particular technology (Rogers, 1983; Ruttan, 1996; Ruttan \& Hayami, 1984). Altogether, this act of non-adoption stems from the lack of resource endowment of smallholder farmers (Doss, 2013). The failed-market induce behaviour suggest characteristics of market failure such as the absence of capital and the factor of production that facilitates the acquisition, procurement and management of the other facets of production, namely, land, labour, and entrepreneur (management) influences decision to adopt innovative technologies (de Janvry \& Sadoulet, 2006; Amadu et al., 2020). In agriculture, capital for investment is a catalyst for technology adoption and lubricant and lifeblood of the rural economy and influences the decision to adopt farm production technologies (Akinola, 2013).

These models have been extensively tested using data from developing and developed countries, investigating especially factors behind the use of chemical fertilizers and improved seed varieties (e.g. Green \& Ng'ong'ola, 1993; Adesina \& Baidu-Forson, 1995; Adeogun et al. 2010; Buah et al., 2011; 
Caswell et al., 2001). However, studies are limited on how these theories are used to understand access to financial credits among smallholders' influence decisions to adopt improved SSA technologies. This study expounds on these theories to explore how access to financial credits by smallholders is critical to influencing farmers' decisions to adopt improved planting technologies to enhanced agricultural productivity. For instance, studies conducted in SSA indicates that apart from the smallholders' enduring intensification dilemma to adopt or not to adopt improved technologies (Quarshie \& Abdulai, 2021), the burden of the high cost involved in adopting modern technologies enmeshed within seed value chain constraints (Quarshie et al., nd), many smallholder farmers do not possess enough capital to purchase inputs or access mechanization services mainly due to poor savings culture, other social commitments, paying for education for children or paying for health care (Banerjee \& Duflo, 2011) as shown in the theoretical framework (Figure 1) below.

Figure 1: Theoretical Framework

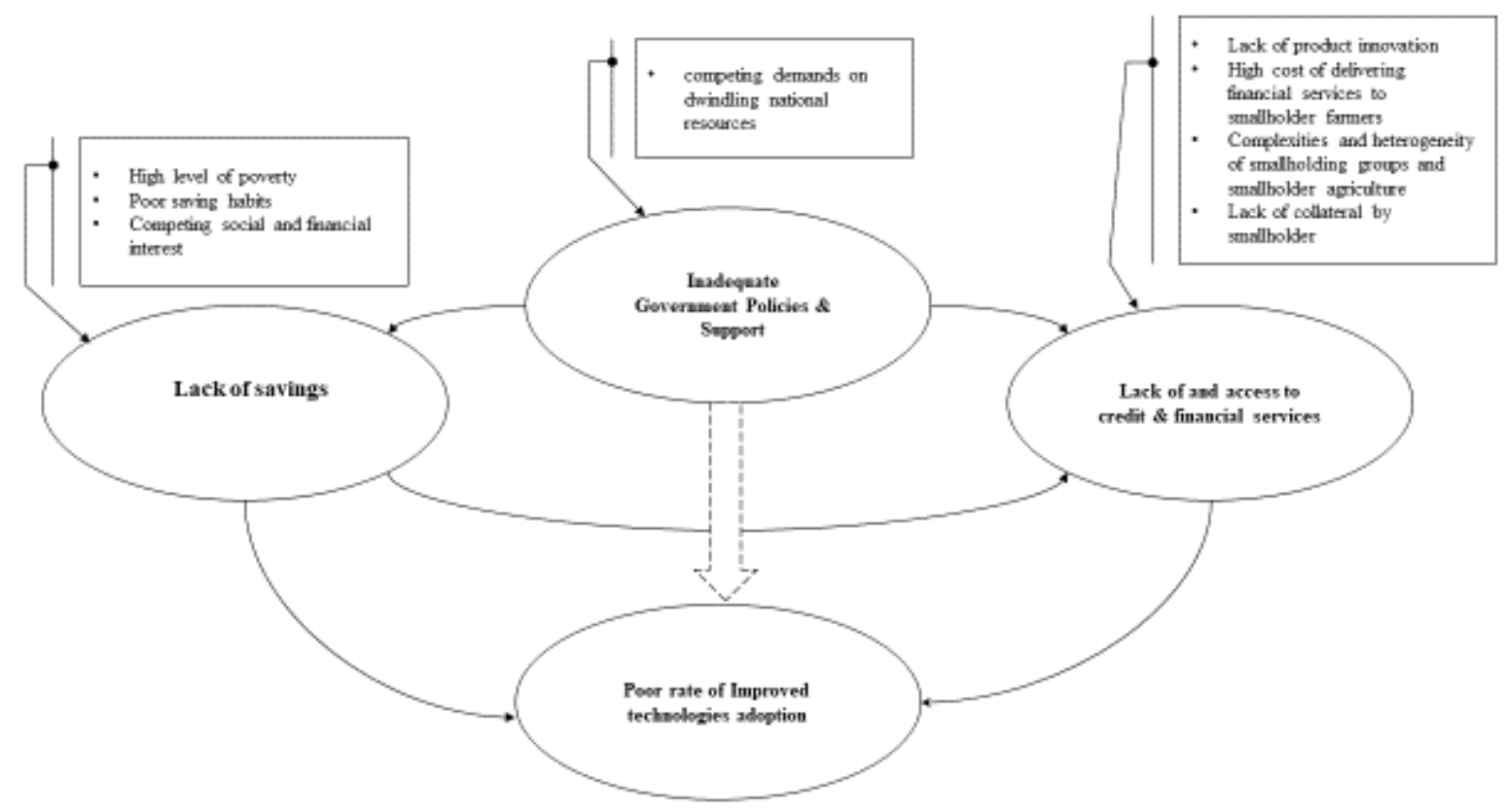

Source: Authors, 2021

The International Finance Corporation of the World Bank suggests financing for agriculture in developing countries is scarce, even for large investors with less than $1 \%$ of commercial lending destined to the agriculture sector (AfDB, 2013). Policy incentives that facilitate access to finance and 
credits to smallholders are as effective and politically easier than designing insurance schemes that increase the social cost (Fœhn \& Isaksen, 2016). However, the lack of government incentives and policies to facilitate farmers' access to financial services in most country as suggested by (AGRA, 2018) also constraints technology adoption among Africa's smallholder farmers. The heterogeneity and complexity of smallholding agriculture and smallholders make it very difficult for credit and finance institutions to design specific products tailored to meet their needs (Fan et al., 2013). Financial institutions in most poor regions argue that the high cost involved in providing loans to farmers and monitoring farmers' activities deters them from working with smallholder farmers (AGRA, 2020; Banerjee \& Duflo, 2011; Meyer, 2013; 2015). Furthermore, the illiteracy rate among smallholders affects access to agricultural finance (Miller \& Jones, 2010). Likewise, the inadequate crop insurance products available to smallholders affect the uptake of improved technologies (Brune et al., 2015).

There is a vast potential for increased food security and rural livelihood improvement embedded within investment in access to credit and finances for smallholder farmers (Poulton et al., 2010; Agarwal, 2013; Reganold \& Wachter, 2016). The call to improve access to credits and financial services to enable smallholders to access loans to adopt the needed technologies required for agricultural transformation is one that is made by governments, development partners and practitioners to avoid food crises (Banerjee \& Duflo, 2011; Agarwal, 2013; Banerjee et al., 2017).

This is because agricultural productivity in the coming years is expected to decline due to the impact of the covid-19 pandemic impact of the African food systems (Ali et al., 2020; Ayanlade \& Radeny, 2020). Challenges such as the rising cost of input that came with the locked-down measures that nations in the region put in place to control the spread of the virus (Yaya et al., 2020), the market closure, which affected smallholders because they couldn't send their produce to market (Reuters, 2020) and the evidence that the virus will persist for the next two years, infesting more people in the region (Scudellari, 2020) is likely to trigger poor agricultural productivity, high level of food insecurities and exacerbating poverty among smallholders in the region. Currently, rice production in the region is predicted to decline (Fernandes, 2020). The African Union (A.U.) has called on nations in the region to embrace a comprehensive recovery plan that addresses the lack of investment in smallholding agriculture (Moseley \& Battersby 2020). Therefore, this paper explores the linkages between agricultural finance and its impact on technology adoption among smallholder farmers in Ghana. 


\subsection{Research Setting Design and Methods}

Figure 2: Map of Study Area

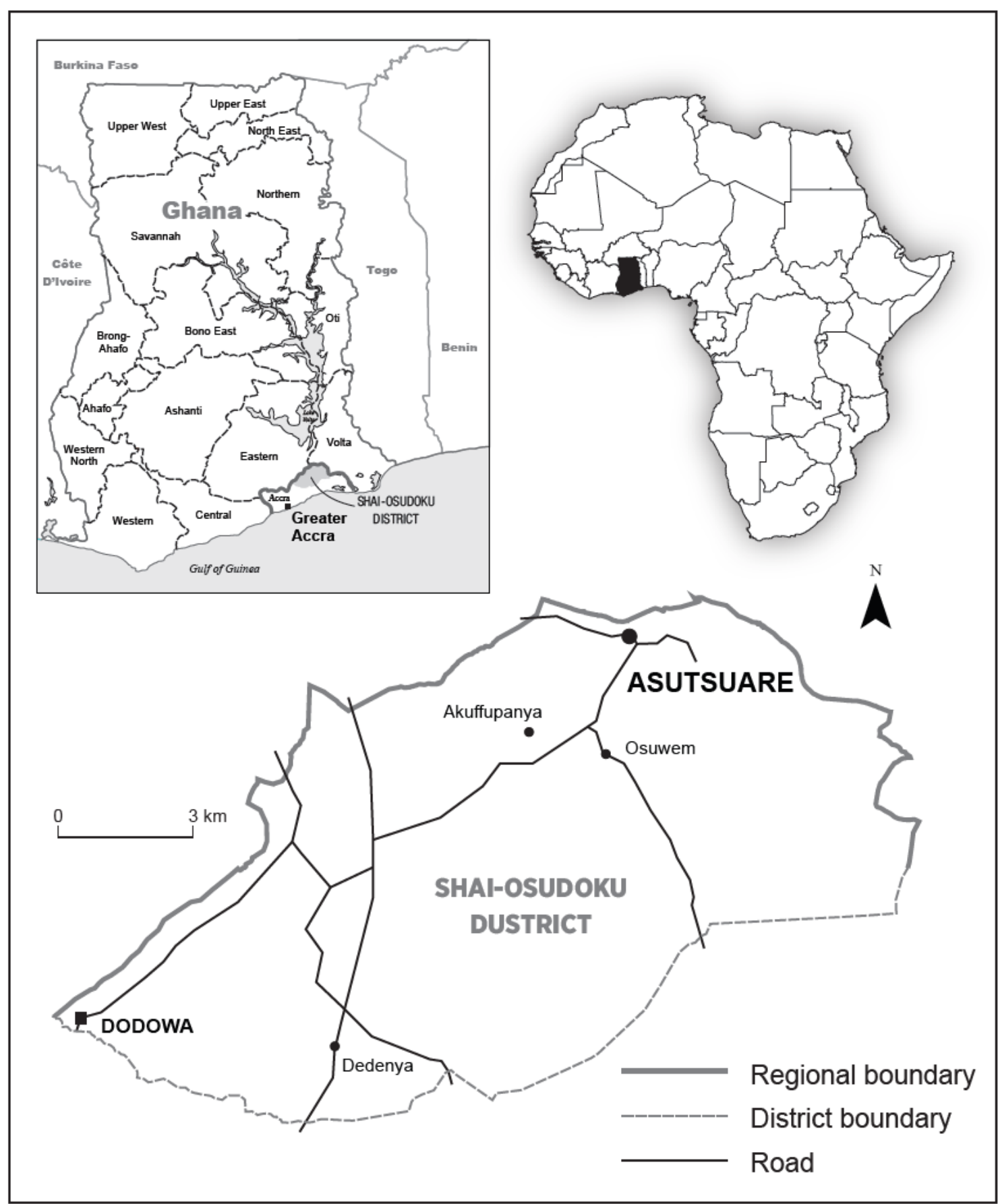

The study was conducted in Asutsuare, located in the Shai-Osudoku District of Ghana (Figure 2). The district is situated at Latitudes 5045' and 6005' degrees north and longitude 0005'E AND 0020'W in the southeastern part of Ghana in the Greater Accra Region. The decision to focus the research in this particular area is because the district is one of the leading rice producers in Ghana and rice production 
output from Asutsuare is the highest due to the presence of irrigation facilities for rice production in the town (MoFA, 2015; 2017). It has a population size of 67,105 , out of which 32,680 are males and 34,425 females and covers a total land surface area of 968.36 square kilometres (GSS, 2014). Agriculture is the primary economic activity of the district, employing about $58.6 \%$ of the economically active population (MLGRD, 2021). The $22 \mathrm{~km}$ stretch of Lake Volta gives it the advantage of fishing and rice farming. The District shares boundaries with North Tongu to the NorthEast, Yilo Krobo municipality and Upper Manya District to the North-West, Akwapim North Municipality Kpone Katamanso Municipality to the South-West, Ningo-Prampram District to the South and Ada West District to the East (GSS, 2014). The district is located within the Savanah agroecological zone of Ghana and is one of the hottest and driest parts of the country, with mean temperatures reaching $40^{\circ} \mathrm{C}$ during dry seasons. Rainfall is generally deficient, with most erratic rains mainly coming between September and November (GMet, 2021). The selection of the district was informed by the concentration of agricultural activities in those regions and their surrounding rural communities.

This study employed a mixture of participatory learning methods, including focus group discussion (FGDs), key informant interview and structured household survey questionnaire to allow local people the opportunity to participate by sharing their experiences. The study explores how access to loans and credits influences the adoption of modern technologies and farm productivity and the limitations to accessing loans and credits from financial institutions in the Shia-Osuduku District in the Greater Accra Region of Ghana. We complimented the qualitative data with quantitative data obtained through faceto-face interviews with key informants purposively chosen for the study. The random sampling technique was used to sample 100 participants for the study (supplementary sheet (A)). A team of researchers was trained to administer the survey within the farming communities. The respondents were randomly selected based on their availability at the time of the study. The was no voice recording for this research due to participants' reference. However, comprehensive notes were taken to advance the analysis of responses from the survey further. The cleaned, coded data were entered into an excel sheet to produce descriptive statistical figures as needed. The Nvivo 11 application tool was used to analyzed qualitative elements of the survey. The coding process focused on themes that show access to credits and financial instruments and how these affect farmers' abilities to adopt improved technologies for enhanced productivity and improve their livelihoods. The qualitative data mainly formed the basis of this paper and was complemented with quantitative data. 


\subsection{Study Results and Findings}

\subsection{Objective 1: To assess the challenges rice farmers face in accessing finance in the Shai- Osudoku district}

Among the many challenges identified by this research as barriers to accessing credits to adopt improved rice production among smallholder farmers are lack of and absence of the following; capital, collateral, guarantor, the difficulty to access information on financial instruments, and the deterrent by high-interest rates. For instance, a field interview with one female smallholder suggest:

"After I witnessed how AGRA rice and ammonia fertilizer can give good yields at the agric officer's (Government Agriculture Extension Officers) field demonstration site, I wanted to invest in it. But the susu group (village savings \& loan group) said I don't have a guarantor for the loan, so they cannot give me the money."

\section{- female farmer}

Further investigation from the village savings and loan suggests, most of these smallholders refuse to pay back the loan after harvest, and so a guarantee for the loan is the surest way to ensure they pay back the loan. They argue, "some of these smallholders even go to the extent of using the money for another purpose apart from rice production, and they will give you stories of how pest and birds have eaten their rice before harvest" - Village Savings \& Loan Officer. On the contrary, some smallholders suggest that even if you have a guarantor required to access the financial credits, the bureaucratic nature of doing business with these village savings and loan groups is a barrier to accessing financial instruments to adopt improved technologies. This was confirmed by another female farmer who suggests;

"My husband was willing to guarantee for me to get a loan to purchase improved rice seeds, but susu group (VSLG) will say bring this document, tomorrow they will say; bring that document. It was back and forth until the rainy season passed, and then they said they are not sure if they give me the loan I can get good yield to pay back."

\section{- Female farmer}


Table 1: Challenges smallholders face in accessing agricultural loans loan

\begin{tabular}{|c|c|c|c|c|c|c|c|c|c|c|c|}
\hline \multirow[b]{2}{*}{ Challenges } & \multirow[b]{2}{*}{ Frequency } & \multirow[b]{2}{*}{$\begin{array}{c}\text { Percent } \\
(\%)\end{array}$} & \multicolumn{2}{|c|}{ Gender (\%) } & \multicolumn{4}{|c|}{ Age Group (yrs) (\%) } & \multicolumn{3}{|c|}{ Education level (\%) } \\
\hline & & & Male & Female & $20-30$ & $31-40$ & $41-50$ & $\begin{array}{l}50 \text { and } \\
\text { above }\end{array}$ & $\begin{array}{c}\text { Junior } \\
\text { High } \\
\text { School }\end{array}$ & $\begin{array}{c}\text { Senior } \\
\text { High } \\
\text { School }\end{array}$ & Tertiary \\
\hline Savings Capital & 17 & 17 & 53 & 47 & 71 & 12 & 17 & 0 & 47 & 35 & 18 \\
\hline collateral & 6 & 6 & 33 & 67 & 66 & 17 & 17 & 0 & 50 & 33 & 17 \\
\hline guarantor & 12 & 12 & 58 & 42 & 25 & 25 & 25 & 25 & 50 & 33 & 17 \\
\hline bureaucracy & 36 & 36 & 56 & 44 & 11 & 64 & 14 & 11 & 56 & 30 & 14 \\
\hline $\begin{array}{l}\text { Access to } \\
\text { information }\end{array}$ & 9 & 9 & 56 & 44 & 11 & 56 & 22 & 11 & 56 & 22 & 22 \\
\hline interest rate & 20 & 20 & 55 & 45 & 20 & 45 & 20 & 15 & 15 & 25 & 60 \\
\hline Total & 100 & 100 & & & & & & & & & \\
\hline
\end{tabular}

Source: Authors, 2021 
The distribution above (Table 1) shows that $64 \%$ of smallholders between the ages of $31-40$ years argue that the financial institutions' bureaucracy is a significant challenge for accessing loans for technology adoption. Again from table 1 above, the study noted $67 \%$ of females between the ages of 20 - 30 years perceived their lack of collateral hinders their access to credit to adopt rice technologies. Furthermore, $71 \%$ of respondents between the ages of 20 - 30 years interviewed in the survey confirmed that their inability to provide savings capital with the banks or VSLG constraints their ability to access loans to adopt these rice technologies.

\subsection{Objective 2: To determine if access to finance impacts the adoption of modern rice production technologies}

The study noted that due to the high level of poverty among smallholder farmers, access to credit facilities from VSLG, microfinance and banks is the only means of accessing and investing in modern rice technologies for improved productivity. This situation was confirmed through the FGDs when a group of smallholders suggest;

"Although improved technologies guarantee good yields, we are poor farmers and cannot afford them unless we get some financial support from government or we get loans from banks to invest in these technologies."

\section{- Focus Group Discussion}

The field survey confirmed this assertion as many smallholder farmers believe their decision to adopt improved technologies is anchored on their ability to access credit facilities from financial companies. The distribution below (Figure 3) shows how farmers perceived access to finance and credits as the catalyst to adopt improved modern technologies. A total of $88 \%$ of the respondents believe their decision to adopt improved technologies is influenced by their access to loans and credit instruments from banks and financial institutions. 
Figure 3: Distribution of responses on how access to finance affect modern technologies adoption

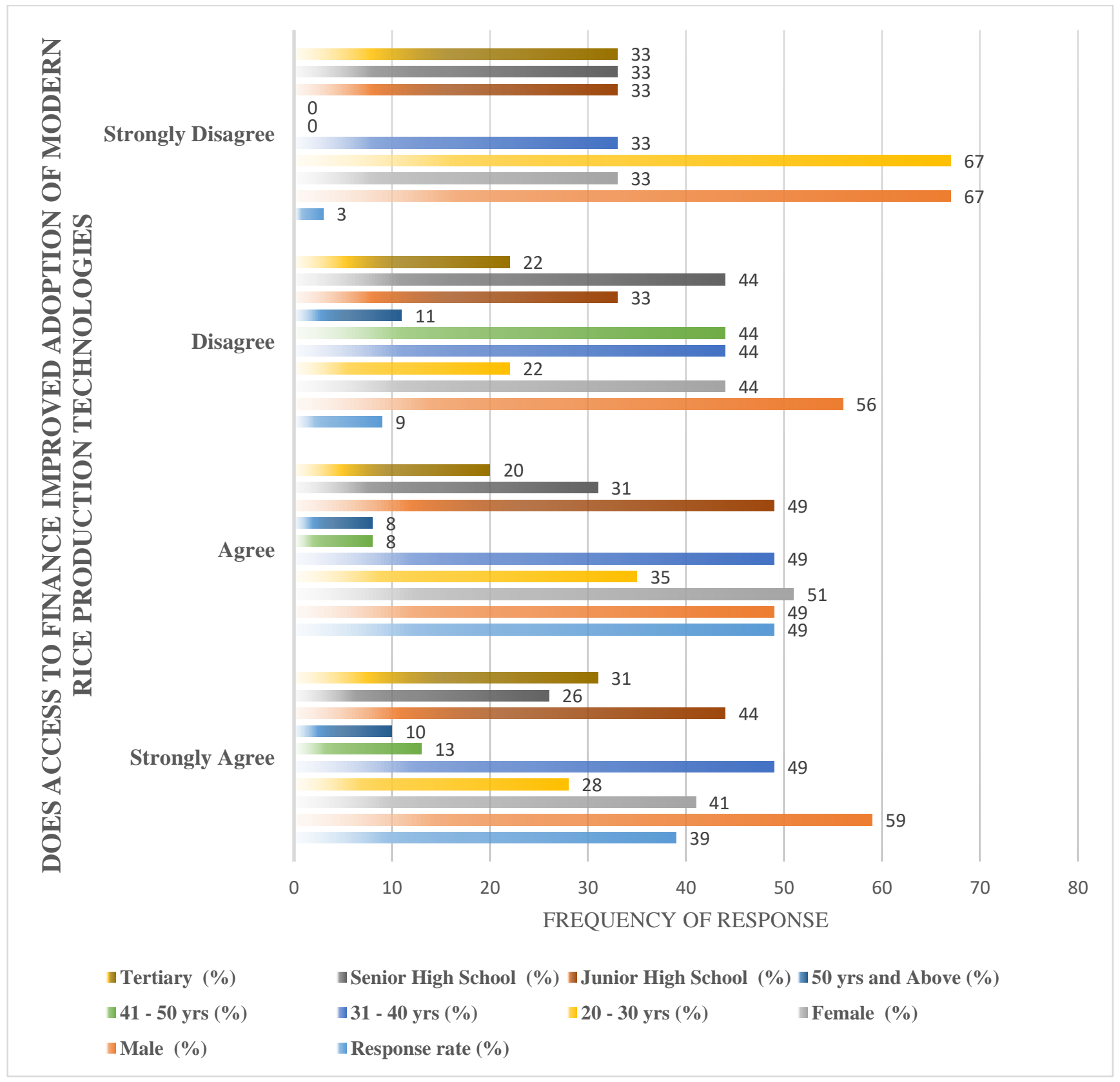

Source: Authors, 2021

In a follow-up interview to understand if the VSLGs, microfinance and banks have adequate information on farmers needs to access credits to be able to adopt improved technologies for enhanced productivity, a bank officer suggested; 
The operational cost to monitor loans and credits given to these smallholder farmers to invest in rice production technologies is much higher than the loan they require. Therefore, we don't have incentives to provide them with funds on an individual basis except they come as a group."

\section{- Bank officer}

This assertion was confirmed from bank records, showing that banks were willing to give out credit to other sectors than smallholding agriculture. The distribution below (Figure 4) shows how much loan funding a rural bank has provided to both agriculture and non-agriculture sectors in the study area between the 2013 - 2017 financial year.

Figure 4: Trends in credit/loan provision by a rural bank in the study area.

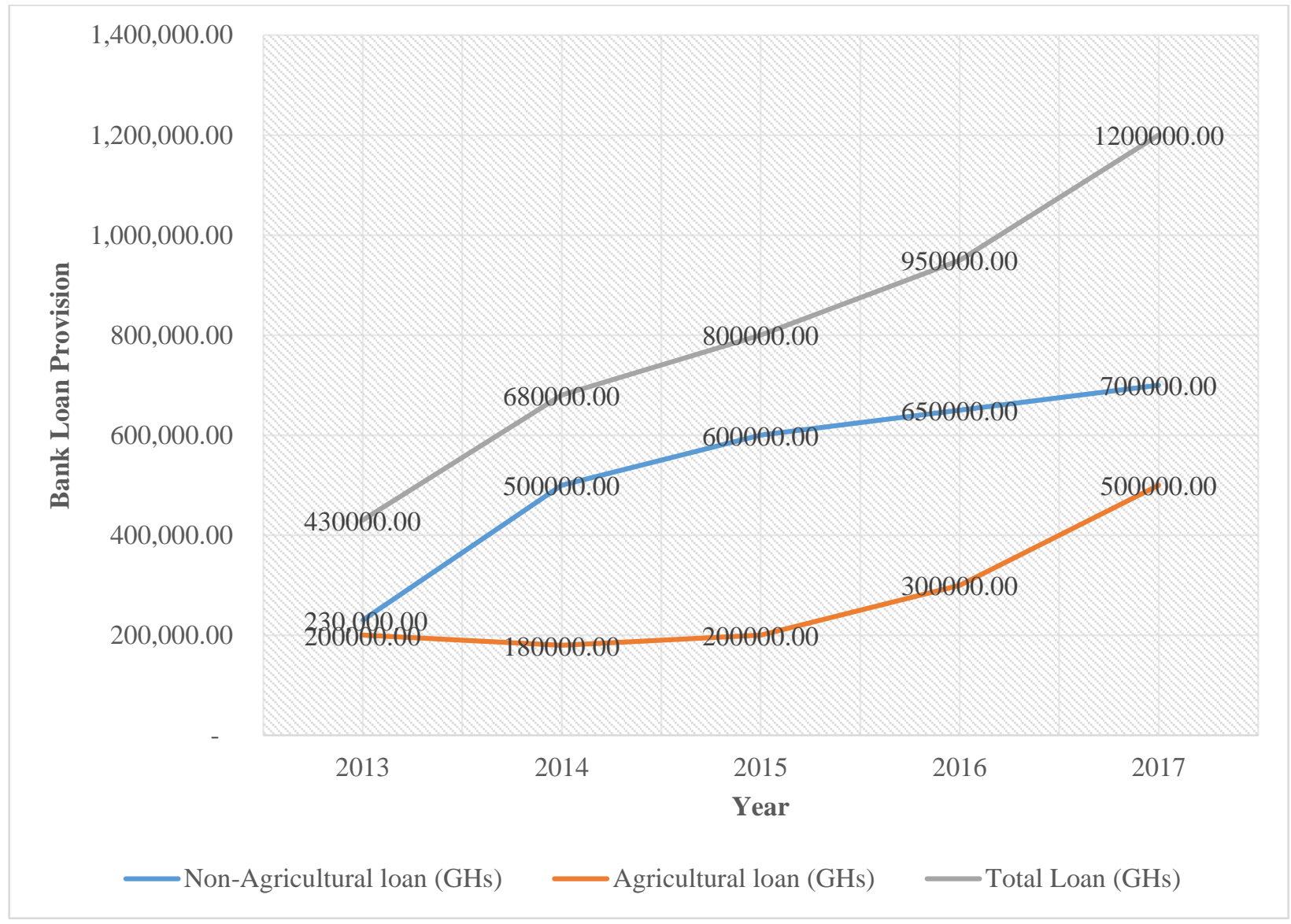

Source: Authors, 2021

From the above figure, we notice a substantial increase in credit facilities given by the rural bank to both the agriculture and non-agriculture sectors between 2013 - 2017. However, the banks are 1 to 3 times more likely to give out credit to the non-agricultural sector than smallholders who require support to invest in modern rice production technologies. For instance, in 2017, out of the total GHs 1,200,000 
the rural bank gave out as credit, only GHs500,000.00 came to support rice smallholders in the study area.

\subsection{Objective 3: To determine whether loan investments in improved technologies increase productivity and income levels of farmers in the Shai-Osudoku District.}

The study result shows that farmers who could access credits and other financial instruments usually adopt improved rice technologies, leading to improved productivity. For instance, an interaction with a farmer who is celebrated as the wealthy farmer among the smallholders suggests access to credit facility is by luck. And has the potential to result in agricultural productivity if the money is invested in improved rice technologies.

"If you are lucky and you get money from the bank on time, and you invest it in modern technologies, you are sure of a good yield, all things being equal."

\section{- smallholder farmer}

The household survey result pointed out that $61 \%$ of rice farmers in the study area believe in the assurance that loans invested in modern rice technologies lead to improved productivity, food security and rural household economic wellbeing. Some even suggest that although VSLG and banks give them credit accompanied by a high-interest rate, they can pay back the principal with interest because of assurance for good yields derived from the adoption of improved technologies. Again, the study noted some smallholder farmers procure crop insurance protection from insurance companies with part of the loans they secure from financial institutions. This insurance mechanism helps them get a total rebate for their investment during harvest failure. This facilitates their ability to pay back both loans and interest to these financial institutions. This was confirmed by an officer from a microfinance company who suggested;

"farmers who invest in the modern technologies especially improved seeds and fertilizer and proper farm management practices do get yields and can pay back their loan on time."

-Microfinance company officer 
Figure 5: Distribution showing how farmers perceived access to finance ultimately leads to technology adoption and enhanced productivity

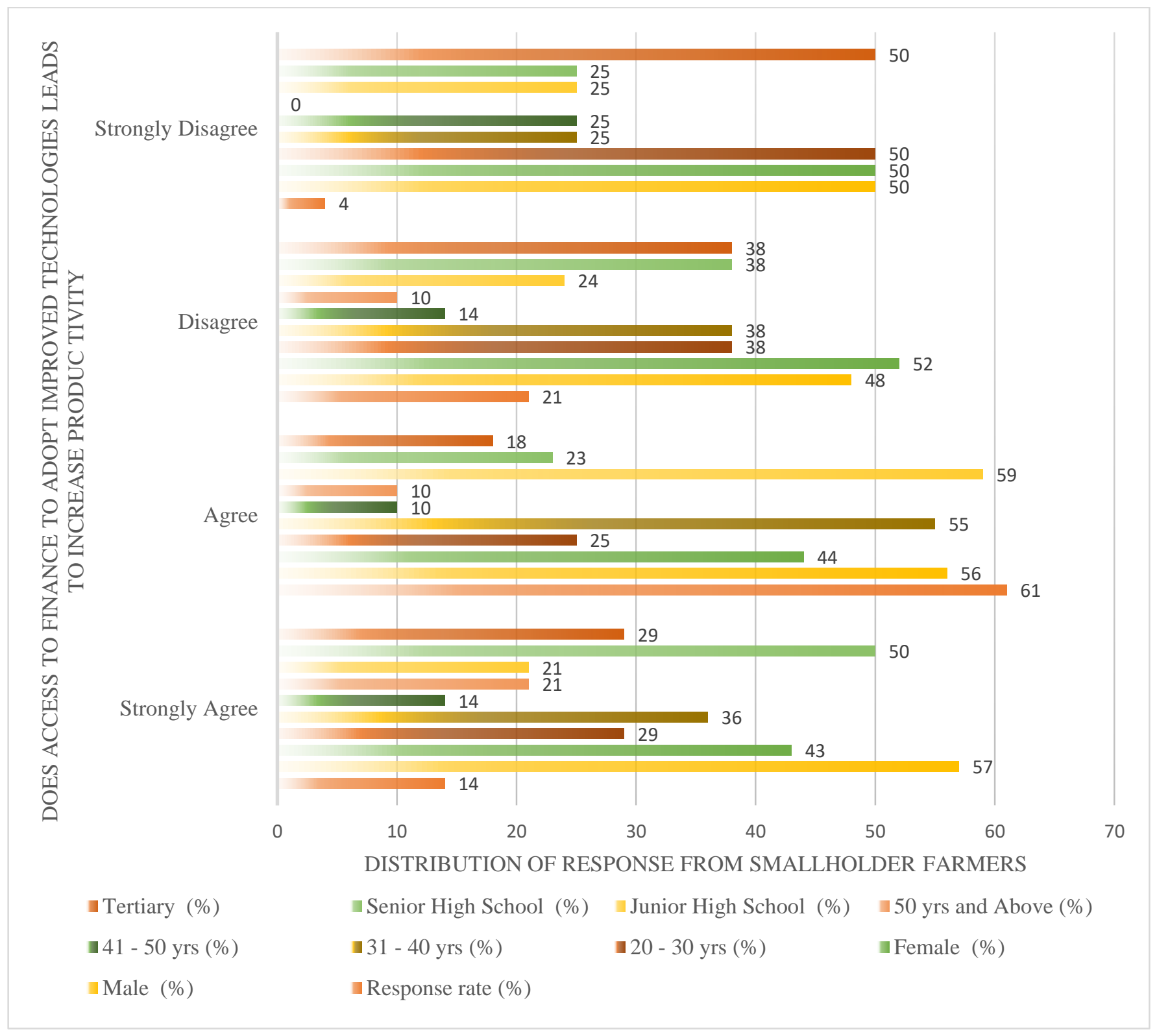

Source: Authors, 2021

The data analysis from the household survey shown in Figure 5 above indicates the linkages between farmers' perception of access to loans for investment in modern technologies and rural household economic wellbeing. The study noted $61 \%$ of these farmers, particularly between the ages of $20-30$ years, strongly argue that their ability to achieve agricultural productivity and rural household wellbeing is anchored on their ability to access credits for technology adoption. 


\subsection{Discussions}

The study noted that the biggest obstacle smallholders face in accessing credit and loans to invest in agricultural technologies is the banks and financial institutions' lack of trust in smallholders' ability to pay back loans (see figure 6). The lack of trust issues has culminated in financial institutions' unwillingness to make credit available and accessible to smallholders for technology adoption. The institutional mistrust is given expression through financial institutions unwilling to share information on innovative solutions and products to smallholders, the request by banks and financial institutions for the massive sum of savings capital by smallholders before loans can be granted. The demand for outrageous collateral from smallholders and, to some extent, multiple guarantors for credits, highinterest rate, bureaucracy and delay in processing loans for smallholders and the willingness of rural banks to give credit out easily to non-agricultural sectors than smallholder farmers is an expression of lack of trust by these institutions to make credit available to smallholders.

Figure 6: Diagram illustrating challenges farmers face in accessing credits/loans

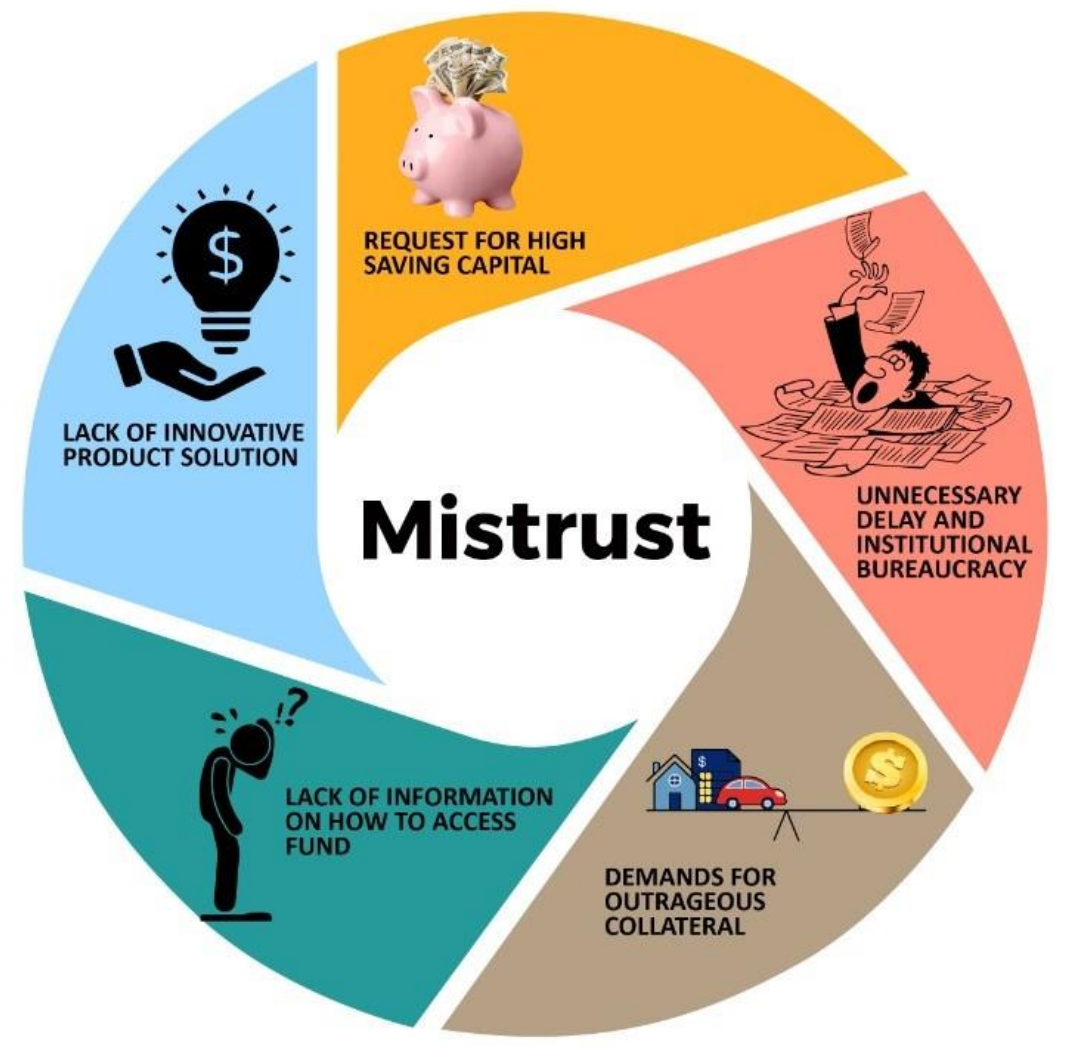

Source: Authors, 2021 
The study noted a strong relationship between access to finance and loans to invest in improved technologies and farmers' productivity. Smallholder farmers who had access to loans and credits can invest in improved rice production technologies, leading to high productivity and income. This experience positions smallholding agriculture as a tool for food security and rural poverty reduction, as suggested by (Lin et al., 2001; UNDP, 2017; AGRA, 2020). This is demonstrated in farmers' perseverance to access loans and credit to invest in modern rice technologies to achieve food security and rural household economic wellbeing. However, issues of mistrust by finance and credit institutions in farmers' ability and willingness to pay back loans limit these institutions' ability to enhance farmers' access to credit facilities. The issue of mistrust is enmeshed within institutional induced-behaviour and actions such as a request for outrageous collateral for loans, high-interest rate, delays and bureaucratic process in accessing loans from these institutions, request for multiple guarantors and vast sums of savings before loans could be approved for smallholders and the rural banks' willingness to provide credits and loans to other sectors apart from smallholding agriculture.

Smallholder farmers also mentioned that agriculture and farm production activities are time-bound and tied to "nature's clock," particularly the rainy season. The issue of bureaucracy and delay caused by financial institutions in approving loans affects farm productivity investment. Most often, loans are approved when the farming season is ending, and farmers end up using the loan for something different for the purpose to which it was secured. Financial institutions perceive such an outcome as farmers' unwillingness to use acquired loans for the intended purpose and, in most cases, farmers' inability to pay back the loan. This situation creates mistrust for smallholders. Hence, banks and financial institutions are unwillingness to approve similar credits and loans to other smallholder farmers or come out with innovative solutions to address the wide gap between agricultural loans and non-agricultural loan funding in rural areas communities.

The lack of proper personal identification credentials by smallholders and the lack of participation in farmer group associations makes it difficult for banks and financial institutions to grant smaller amount of loans due to the high operational cost in monitoring this funds compared to disbursing large sums of money to farmer group association and monitor it at the association level instead of having to supervise many farmers farm production activities for reporting purpose. This situation confirms the IFC's long-standing suggestion that challenges of personal identification and lack of participation in farmer association groups in many developing countries thwart efforts to improve agricultural financing and investments in new production technologies (IFC, 2011). 


\subsection{Policy Recommendation}

Whiles there is growing evidence that access to finance by smallholders can lead to investment in improved technology adoption which is required to increase agricultural productivity, the challenges associated with securing agricultural loans and credits should be minimized to make agricultural loans and credit finance more accessible to smallholder farmers. The Approval and disbursement of loan finance at the wrong time is not beneficial to smallholding agriculture as most farmers would have missed the planting season, which correlates to the onset of the rainy seasons. This situation forces smallholders to misuse the approved loans and credit on other demands. The paper makes the following recommendations to enhance farmers access to loans for investment in improved technologies;

Government support for the sector is required via the introduction of an agriculture insurance policy system and products that can mitigate the challenges of non-payments during harvest failure and crop losses among smallholder farmers. This is essential to addressing the issues of mistrust among financial institutions for smallholder farmers. Whiles, we encourage smallholder farmers to developed a saving culture and also join farmer group associations for collective bargaining for loans and credits instruments, a policy to introduce a warehouse receipt system that can support smallholder farmers use of their farm produce as collateral to access loans from financial institutions would go a long way to address the issues of non-savings and lack of collateral and guarantors to access loans. The banks and financial institutions must employ innovative ways to reduce the bureaucracy in processing loan facilities by implementing strategies that help them address loan default issues. Furthermore, financial institutions should make more effort in educating farmers on their processes and requirements to acquire loans before the onset of the rainy season. This is critical to enabling smallholders to enable to prepare adequately before applying for credit.

Furthermore, the need for specialized financial institutions that understands the agriculture production cycle and smallholding agriculture is critical to enhancing farmers' access to financial instruments for investment in modern technologies to achieve food security and rural household economic wellbeing. Finally, we argue that all these should be done with more significant consideration to female smallholders. They make up most of those affected by banks and financial institution's decisions to not approve loans and credit for investment in smallholding agriculture. Sub-Saharan Africa's food production efforts would be significantly undermined if policy efforts neglect critical roles being played by female smallholders who have taken on roles as food production and managers of home food 
(Agarwal, 2013), as well roles as caregivers of the sick and old throughout the covid-19 pandemic (Moseley \& Battersby, 2020).

\section{Conclusion}

While farmers are optimistic about their ability to increase productivity to address food insecurities and rural poverty via investments in improved planting technologies, barriers to accessing loans and credits from financial institutions, particularly the issue of mistrust, require much attention to enhance farmers' access to credits instruments. The study noted that issues of mistrust as a result of failedmarket induces institutional behaviour, which manifests through institutional behaviour and actions such as bureaucratic processes and delays in loan processing, request for huge collateral and guarantors by banks and other financial institutions, high-interest rates and request for huge savings capital with banks before loans are approved. This situation influences farmers' decisions to adopt improved production technologies. Although there is growing evidence that rural banks are willing to approve loans for the non-agricultural sector than smallholding agriculture, much attention must be given to smallholder farmers because they much of SSA active population and contributes much to the region's GPD whiles producing most of Africa's food needed to feed her growing population who are increasingly urbanized. Access to finance influences smallholder farmers' ability to adopt modern technologies. Hence, the more smallholders access available credit instruments, the higher their chances of adopting planting technologies. Furthermore, access to agricultural finance also increases agricultural productivity via investment in improved planting technologies, which is critical to positioning smallholder agriculture as a tool to achieve Africa's food security and improved rural household economic wellbeing.

Acknowledgements: The authors acknowledge Dr. Napoleon Kurantin for supervising the lead author's MA thesis. We credit the map of the study area to Marie Puddister, University of Guelph, Ontario, Canada

Ethics Declarations: All research was conducted in a manner that does not jeopardize respondents physically, mentally, and socially according to the Ghana Institute of Management and Public Administration students' research guidelines. Informed consent was sort from every participant before the survey and interview were conducted. The study aimed to understand farmers' perception of the 
impact of financial credits on improved planting technologies adoption and agricultural productivity. This research is void of any personal, biological data of respondents.

Data Availability Statement: The data supporting the findings of this study are partly available in this work and attached to the manuscript as supplementing materials. Further enquiries can be directed to the corresponding author(s)

\section{References}

Adeogun, S. O., Olawoye, J. E., \& Akinbile, L. A. (2010). Information sources to cocoa farmers on cocoa rehabilitation techniques (CRTs) in selected states of Nigeria. Media and Communication Studies, 9-15.

Adesina, A. A., \& Baidu-Forson, J. (1995). Farmers' perceptions and adoption of new agricultural technology: evidence from analysis in Burkina Faso and Guinea, West Africa. Agricultural Economics Vol 13, 1-10.

African Development Bank. (2013). Agricultural Value Chain Financing (AVCF) and Development for Enhanced Export Competitiveness (Rep.). Tunis

Agarwal, B. (2013). Food Security, Productivity, and Gender Inequality (R. J. Herring, Ed.; Vol. 1). Oxford University Press. https://doi.org/10.1093/oxfordhb/9780195397772.013.002

AGRA. (2018). Africa Agriculture Status Report, 2018. AGRA Nairobi.

AGRA. (2020). Africa Agriculture Status Report 2020: Feeding African Cities-Opportunities, Challenges, and Policies for Linking African Farmers with Growing Urban Food Markets. Alliance for a Green Revolution in Africa (AGRA). https://agra.org/wpcontent/uploads/2020/09/AASR-2020-Feeding-African-Cities.pdf

Akinola. F (2013). The Challenges Of Agricultural Finance In Nigeria: Constraints To Sustainable Agricultural And Economic Revival. Department Of Accounting And Finance Faculty Of Social And Management Sciences Ajayi Crowther University, Oyo State, Nigeria.

Ali, Z., Green, R., Zougmoré, R. B., Mkuhlani, S., Palazzo, A., Prentice, A. M., Haines, A., Dangour, A. D., \& Scheelbeek, P. F. D. (2020). Long-term impact of West African food system responses to COVID-19. Nature Food, 1(12), 768-770. https://doi.org/10.1038/s43016-020-00191-8

Amadu, F. O., McNamara, P. E., \& Miller, D. C. (2020). Understanding the adoption of climate-smart agriculture: A farm-level typology with empirical evidence from southern Malawi. World Development, 126, 104692. https://doi.org/10.1016/j.worlddev.2019.104692 
Amanor, K. S. (2011). From Farmer Participation to Pro-poor Seed Markets: The Political Economy of Commercial Cereal Seed Networks in Ghana. IDS Bulletin, 42(4), 48-58. https://doi.org/10/cj484m

Ayanlade, A., \& Radeny, M. (2020). COVID-19 and food security in Sub-Saharan Africa: Implications of lockdown during agricultural planting seasons. Npj Science of Food, 4(1), 13. https://doi.org/10.1038/s41538-020-00073-0

Baidu-Forson, J. (1999). Factors influencing adoption of land-enhancing technology in the Sahel: lessons from a case study in Niger. Agricultural Economics 20, 231-239 .

Banerjee, A. V., \& Duflo, E. (2011). Poor Economies: Radical Rethinking of the way to fight Global Poverty. PublicAffairs.

Banerjee, S. G., Malik, K., Tipping, A., Besnard, J., \& Nash, J. (2017). Double Dividend: Power and Agriculture Nexus in Sub-Saharan Africa. 250.

Boansi, D., \& Favour, R. (2015). Why the Persistent Increase in Ghana's Rice Imports? Prescriptions for Future Rice Policy. Asian Journal of Agricultural Extension, Economics \& Sociology, 7(4), 1-21. https://doi.org/10.9734/AJAEES/2015/18834

Caswell, M., Fuglie, K., Ingram, C., Jans, S., \& Kascak, C. (2001). Adoption of Agricultural Production Practices: Lessons Learned from the U.S. Agricultural Economic, 1-110.

Dawson, N., Martin, A., \& Sikor, T. (2016). Green Revolution in Sub-Saharan Africa: Implications of Imposed Innovation for the Wellbeing of Rural Smallholders. World Development, 78, 204218. https://doi.org/10/gf5b29

de Janvry, A., \& Sadoulet, E. (2006). Progress in the modeling of rural households' behavior under market failures. Poverty, Inequality and Development, 155-181

Evans, A. (2009). The feeding of the nine billion: Global food security for the 21st century,. Royal Institute of International Affairs Fan, S., Brzeska, J., Keyzer, M., \& Halsema, A. (2013). From subsistence to profit: Transforming smallholder farms. Food policy report. Washington, D.C.: International Food Policy Research Institute (IFPRI).

Fan, S., Brzeska, J., Keyzer, M., \& Halsema, A. (2013). From subsistence to profit: Transforming smallholder farms. Food policy report. Washington, D.C.: International Food Policy Research Institute (IFPRI).

Fœhn, T., \& Isaksen, E. T. (2016). Diffusion of Climate Technologies in the Presence of Commitment Problems. The Energy Journal, 37(2), 155-180.

Foley, J. A., Ramankutty, N., Brauman, K. A., Cassidy, E. S., Gerber, J. S., Johnston, M., Mueller, N. D., O’Connell, C., Ray, D. K., West, P. C., Balzer, C., Bennett, E. M., Carpenter, S. R., Hill, 
J., Monfreda, C., Polasky, S., Rockström, J., Sheehan, J., Siebert, S., ... Zaks, D. P. M. (2011).

Solutions for a cultivated planet. Nature, 478(7369), 337-342. https://doi.org/10.1038/nature10452

Gassner, A., Harris, D., Mausch, K., Terheggen, A., Lopes, C., Finlayson, R., \& Dobie, P. (2019). Poverty eradication and food security through agriculture in Africa: Rethinking objectives and entry points. Outlook on Agriculture, 48(4), 309-315. https://doi.org/10.1177/0030727019888513

Ghana Statistical Service. (2014). 2010 Popullation and Housing Census. Accra: Ghana Statistical Service

GMet. (2021). District Fact Sheet. Accra: Ghana Meteorological Agency

Godfray, H. C. J., \& Garnett, T. (2014). Food security and sustainable intensification. Philosophical Transactions: Biological Sciences, 369(1639), 1-10. JSTOR.

Green, D. A., \& Ng'ong'ola, D. H. (1993). Factors Affecting Fertilizer Adoption In Less Developed Countries: An Application Of Multivariate Logistic Analysis In Malaŵi. Agricultural Economics, 99-109.

Hayami Y \& Ruttan V W. (1985). Agricuitural development: an international perspective.

Holt Giménez, E., \& Shattuck, A. (2011). Food crises, food regimes and food movements: Rumblings of reform or tides of transformation? Journal of Peasant Studies, 38(1), 109-144. https://doi.org/10.1080/03066150.2010.538578

Howard, J., Crawford, E., Kelly, V., Demeke, M., \& Jeje, J. J. (2003). Promoting high-input maize technologies in Africa: The Sasakawa-Global 2000 experience in Ethiopia and Mozambique. Food Policy, 28(4), 335-348. https://doi.org/10/fdfhrj

International Finance Corporation. (2011). Scaling Up Access to Finance for Agricultural SMEs Policy Review and Recommendations (Rep.). International Finance Corporation

Jerving, S. (2020, December 22). U.N. food systems envoy warns of double threat to food security in Africa next year. Devex. https://www.devex.com/news/sponsored/un-food-systems-envoywarns-of-double-threat-to-food-security-in-africa-next-year-98817

Juma, C. (2015). The New Harvest: Agricultural Innovation in Africa. Oxford University Press.

Kansanga, M., Andersen, P., Kpienbaareh, D., Mason-Renton, S., Atuoye, K., Sano, Y., Antabe, R., \& Luginaah, I. (2018). Traditional agriculture in transition: Examining the impacts of agricultural modernization on smallholder farming in Ghana under the new Green Revolution. International Journal of Sustainable Development \& World Ecology, 26(1), 11-24. https://doi.org/10.1080/13504509.2018.1491429 
Kc, K. B., Haque, I., Legwegoh, A. F., \& Fraser, E. D. G. (2016). Strategies to Reduce Food Loss in the Global South. Sustainability, 8(7), 595. https://doi.org/10.3390/su8070595

Keyoung, L. (2011). The Role of Culture in Agricultural Technology Diffusion in Ghana, Accra

Lin, L., McKenzie, V., Piesse, J., Thirtle, C., 2001. Agricultural Productivity and Poverty in Developing Countries. Extension to DFID, Report No. 7946.

Lowder, S. K., Skoet, J., \& Raney, T. (2016). The Number, Size, and Distribution of Farms, Smallholder Farms, and Family Farms Worldwide. World Development, 87, 16-29. https://doi.org/10.1016/j.worlddev.2015.10.041

Mausch, K., Harris, D., Heather, E., Jones, E., Yim, J., \& Hauser, M. (2018). Households' aspirations for rural development through agriculture. Outlook on Agriculture, 47(2), 108-115. https://doi.org/10.1177/0030727018766940

Meyer, R.L. (2013). Innovative Microfinance: Potential to serve rural markets sustainably. London.

Meyer, R. L. (2015). Financing agriculture and rural areas in sub-Saharan Africa: Progress, challenges and the way forward (Working paper). London: IIED.

Miller, C., \& Jones, L. M. (2010). Agricultural value chain finance: tools and lessons. Warwickshire, U.K.: Practical Action Pub.

Ministry of Food and Agriculture, G. (2017). Planting for Food and Jobs Roadmap. Accra: Ministry of Food and Agriculture.

MoFA - Statistics, Research and Information Directorate (SRID). (2016). Fact and Figures. Accra: Ministry of Food and Agriculture.

Moseley, W. G., \& Battersby, J. (2020). The Vulnerability and Resilience of African Food Systems, Food Security, and Nutrition in the Context of the COVID-19 Pandemic. African Studies Review, 63(3), 449-461. https://doi.org/10.1017/asr.2020.72

Ministry of Local Government and Rural Development. (2021). About | SHAI-OSUDOKU DISTRICT ASSEMBLY [Government]. MLGRD. https://www.soda.gov.gh/about

Nguezet, P. M., Okoruwa, V., Adeoti, A., \& Adenegan, K. (2012). Productivity Impact Differential of Improved Rice Technology Adoption Among Rice Farming Households in Nigeria. Journal of Crop Improvement, 26, 1-21. https://doi.org/10.1080/15427528.2011.608246

Nin-Pratt, A., \& McBride, L. (2014). Agricultural intensification in Ghana: Evaluating the optimist's case for a Green Revolution. Food Policy, 48, 153-167. https://doi.org/10/ggt374

Nyantakyi-Frimpong, H., \& Bezner Kerr, R. (2015). A political ecology of high-input agriculture in northern Ghana. African Geographical Review, 34(1), 13-35. 
https://doi.org/10.1080/19376812.2014.929971

Osei-Asare, Y. 2010. Mapping of Poverty Reduction Strategies and Policies Related to Rice Development in Ghana. Nairobi, Kenya: Coalition for African Rice Development (CARD).

Poulton, C., Chinsinga, B., \& College, C. (2018). The Political Economy Of Agricultural Commercialisation In Africa. 40.

Poulton, C., Dorward, A., \& Kydd, J. (2010). The Future of Small Farms: New Directions for Services, Institutions, and Intermediation. World Development, 38(10), 1413-1428. https://doi.org/10.1016/j.worlddev.2009.06.009

Quarshie, P., \& Abdulai, A.-R. (2021, February 16). The Enduring Intensification Dilemma of Africa's $\begin{array}{lllll}\text { Rural } & \text { Farmer.pdf } & \text { [USAID } & \text { FtF } & \text { Project]. }\end{array}$ https://www.agrilinks.org/post/enduring-intensification-dilemma-africas-rural-farmer

Reganold, J. P., \& Wachter, J. M. (2016). Organic agriculture in the twenty-first century. Nature Plants, 2(2), 1-8. https://doi.org/10.1038/nplants.2015.221

Reuters. 2020. Zimbabwe reopens produce markets after protests by drought-hit-farmers. Daily Maverick, 20 April. https://www.dailymaverick.co.za/article/2020-04-09-zimbabwe-reopensproduce-markets-after-protests-by-drought-hitfarmers/\#gsc.tab=0.

Rogers, E. M. (1983). Diffusion of innovations (3rd ed). Free Press ; Collier Macmillan.

Ruttan, V. W., \& Hayami, Y. (1984). Toward a theory of induced institutional innovation. Journal of Development Studies, 20, 203-223.

Ruttan, V. W. (1996). What Happened to Technology Adoption-Diffusion Research? Sociologia Ruralis, 36(1), 51-73. https://doi.org/10.1111/j.1467-9523.1996.tb00004.x

Scudellari, M. 2020. How the pandemic might play out in 2021 and beyond. Nature. 584: 22-25 August 5. https://www.nature.com/articles/d41586-020-02278-5

Thornton, P., Jones, P., Ericksen, P., \& Challinor, A. (2011). Agriculture and food systems in SubSaharan Africa in a $4^{\circ} \mathrm{C}+$ world. Philosophical Transactions. Series A, Mathematical, Physical, and Engineering Sciences, 369, 117-136. https://doi.org/10.1098/rsta.2010.0246

Tilman, D., Balzer, C., Hill, J., \& Befort, B. L. (2011). Global food demand and the sustainable intensification of agriculture. Proceedings of the National Academy of Sciences of the United States of America, 108(50), 20260-20264. JSTOR.

UNDP, 2017. Advancing Regional Agro-food Value Chains in Africa Knowledge Sharing Report, New York, USA: United Nations Development Programme 
Vercillo, S., Kuuire, V. Z., Armah, F. A., \& Luginaah, I. (2015). Does the New Alliance for Food Security and Nutrition impose biotechnology on smallholder farmers in Africa? Global Bioethics, 26(1), 1-13. https://doi.org/10.1080/11287462.2014.1002294

Vercillo, S., \& Hird-Younger, M. (2019). Farmer resistance to agriculture commercialisation in northern Ghana. Third World Quarterly, 40(4), 763-779. https://doi.org/10.1080/01436597.2018.1552076

World Bank. (2019). Enabling the Business of Agriculture 2019. https://openknowledge.worldbank.org/bitstream/handle/10986/31804/9781464813870.pdf

Yaya, S., Otu, A. \& Labonté, R. Globalisation in the time of COVID-19: repositioning Africa to meet the immediate and remote challenges. Glob. Health 16, 1-7 (2020). 